\title{
Murillo Fernando Rodrigues
}

Clinas neutras ou adaptativas? Integrando variação genômica clinal e sazonal para inferir seleção natural em Drosophila melanogaster

Adaptive or neutral clines? Integrating genome-wide clinal and seasonal variation to infer natural selection in Drosophila melanogaster 



\title{
Murillo Fernando Rodrigues
}

\section{Clinas neutras ou adaptativas? Integrando} variação genômica clinal e sazonal para inferir seleção natural em Drosophila melanogaster

\author{
Adaptive or neutral clines? Integrating genome-wide \\ clinal and seasonal variation to infer natural selection in \\ Drosophila melanogaster
}

Dissertação apresentada ao Instituto de Biociências da Universidade de São Paulo, para a obtenção de Título de Mestre em Ciências, na área de Genética e Biologia Evolutiva.

Orientador: Prof. Dr. Rodrigo Cogni

Co-orientadora: Prof. Dra. Maria

Vibranovski

São Paulo 


\section{Ficha catalográfica}

Rodrigues, Murillo Fernando

Clinas neutras ou adaptativas? Integrando variação genômica clinal e sazonal para inferir seleção natural em Drosophila melanogaster

$56 \mathrm{p}$

Dissertação (Mestrado) - Instituto de Biociências da Universidade de São Paulo. Departamento de Genética e Biologia Evolutiva.

1. Adaptação 2. Adaptação sazonal 3. Drosophila melanogaster 4. Seleção natural 5. Variação molecular

I. Universidade de São Paulo. Instituto de Biociências. Departamento de Genética e Biologia Evolutiva.

\section{Comissão Julgadora}

Prof(a). Dr(a).

Prof(a). Dr(a).

$\operatorname{Prof}(\mathrm{a}) . \operatorname{Dr}(\mathrm{a})$.

Prof. Dr. Rodrigo Cogni 


\section{Agradecimentos}

Agradeço ao meu orientador, Rodrigo Cogni, por dedicar inúmeras horas ao meu desenvolvimento acadêmico e profissional. Obrigado por propiciar um ambiente acadêmico estimulante, pela paciência e por me ajudar a persistir mesmo em momentos de adversidade. Agradeço à minha co-orientadora, Maria Vibranovski, por sempre estar disposta a me ajudar e por suas sempre pertinentes contribuições.

Aos meus fantásticos colegas de laboratório, Camila, André e Marcos, pelo apoio e ajuda durante os últimos anos. Meu trabalho não teria sido o mesmo sem as contribuições de todos vocês! Obrigado Arthur e Ana, por toda ajuda com as mosquinhas! Agradeço também aos meus colegas de Journal Club pelas discussões de excelentes artigos em Evolução.

Agradeço a todos meus amigos e colegas de pós-graduação da Genética e da Ecologia. Sem o ombro amigo de muitos de vocês, meu tempo no mestrado teria sido muito menos divertido e prazeroso. Também, aprendi muito interagindo com todos vocês!

Um especial agradecimento a todos os professores e funcionários do IB/USP. O IB é um ambiente excelente para um biólogo em formação graças a todos vocês! Agradeço aos membros da minha banca de qualificação, Prof. Dr. Carlos Vilela, Dra. Daniela Rossoni e Profa. Dra. Tatiana Torres. Obrigado ao Gustavo e Lenilda, por sempre me ajudar quando precisei.

Thank you to Professor John Pool (UW-Madison), for hosting me for six months in your lab! I learned a lot from you and your group, and I am extremely thankful for you all making me feel welcome. I thank Chris, Jeremy, Quentin, Tiago and Yuheng for being awesome labmates. Thank you for helping me out during my period there. I am 
extremely thankful to Ellen, for helping me with my project. Thanks Yuheng for our conversations over lunch, you are a great friend! Special thanks to Tiago and Guilherme, for being great friends and instrumental to my well being while I stayed in Madison! I am also thankful to the other graduate students, postdocs and faculty I interacted with during my time at UW-Madison. Thank you Professor Nicole Perna and Dr. Jeremy Glasner for letting me use the microbiology lab and helping me with basic microbiology techniques. Thank you Brenda and family for welcoming me to Madison, and showing me how great midwesterners can be!

Muito obrigado a todos meus amigos e colegas de graduação, que, de muitas maneiras, me tornaram um biólogo e uma pessoa melhor. Em especial, agradeço aos Queridos da Bio, Bunni, Carol, Gabriel, Isa e Nat, por todos momentos especiais que dividimos ao longo dos últimos seis anos. Tem sido ótimo crescer junto com vocês! Carol e Luiza, muito obrigado também por revisarem a dissertação.

Sou imensamente grato à minha namorada, Luiza Ostrowski, por me dar alegrias, carinho e companhia. Você me faz uma pessoa melhor, e contribuiu muito para que eu conseguisse enfrentar esse desafio!

Agradeço de coração toda minha família pelo apoio durante meus anos de graduação e mestrado. Em especial, agradeço minha mãe e meu pai pelo apoio e amor incondicional! Também, agradeço pelo apoio financeiro. Infelizmente, ciência não é prioridade no nosso país e, em anos recentes, isso tem ficado cada vez mais claro.

Agradeço, por fim, a Fundação de Amparo à Pesquisa do Estado de São Paulo (FAPESP), pelo financiamento da minha bolsa de mestrado e bolsa de estágio à pesquisa no exterior. Processos ns 2016/01354-9 e 2017 / 06374-0. 


\section{Resumo}

Variação espacial e temporal são ubíquas. Caracteres são chamados clinais quando variam ao longo de um gradiente ambiental, e isso é interpretado como resultado de seleção estruturada no espaço. Drosophila melanogaster apresenta clinas em diversos caracteres fenotípicos e genotípicos, as quais são replicadas em diferentes regiões do mundo. Estudos recentes sugeriram que grande parte da variação clinal pode ser atribuída a processos neutros. Como o ambiente varia de maneira similar com a latitude e ao longo do ano, e essa variação sazonal é ortogonal à demografia, uma abordagem possível para inferir seleção natural é integrar variação clinal e sazonal. Neste trabalho, nós testamos se há uma relação entre variação clinal e sazonal ao longo do genoma de D. melanogaster. Também, investigamos a proporção de variantes que deveriam estar sob seleção espacial e sazonal para explicar o padrão encontrado. Estimamos a frequência alélica a partir de amostras de pools de moscas coletadas em diferentes oito localidades ao longo da costa leste dos Estados Unidos e em diferentes estações do ano na Pensilvânia, EUA. Nós encontramos um padrão genômico de variação clinal refletindo variação sazonal. Esse padrão é mais forte para variantes em regiões exônicas do que intergênicas, consistente com a ação de seleção. A relação entre variação clinal e sazonal encontrada pode ser explicada se 6,6\% dos polimorfismos estiverem sob seleção espacial e sazonal. Nossos resultados são consistentes com a hipótese adaptativa de variação clinal e, junto com outras observações, revelam que o papel da demografia na manutenção de clinas em $D$. melanogaster é limitado. 


\section{Abstract}

Spatial and temporal variation in the environment are ubiquitous. Traits are called clinal when they vary along an environmental gradient, and this is often interpreted as the result of spatially varying selection. Drosophila melanogaster is known to have many phenotypic and genotypic clines, replicated in many regions of the world. Recent studies have suggested that most clinal variation could be attributed to neutral, demographic processes. Because the environment varies in similar ways with latitude and across seasons, and seasonal variation is orthogonal to demography, one promising approach is to integrate clinal and seasonal variation to infer selection. Here, we test whether there is a genome-wide relationship between clinal and seasonal variation, and whether the pattern is consistent with selection. Also, we investigate the proportion of the variants that should be under latitudinal and seasonal selection to explain the pattern we uncovered. We estimate allele frequency from pooled samples of flies from eight different locations along the east coast of the US, and 13 samples collected in the spring and in the fall in Pennsylvania. We show that there is a genome-wide pattern of clinal variation mirroring seasonal variation. This pattern is stronger for exonic when compared to intergenic regions, consistent with natural selection. We find that the genome-wide relationship between clinal and seasonal variation could be explained by about $6.6 \%$ of our SNPs being under latitudinal and seasonal selection. Our results are consistent with the adaptive hypothesis of clinal variation and, together with other observations, leave little room for the role of demography in maintaining clines in $D$. melanogaster. 


\section{Introduction}

All species are subject to environmental variation structured through space and time. Different environments can impose various selective regimes on populations, resulting in adaptive differentiation. With spatially varying selection, one allele can be beneficial in one environment and disadvantageous in another (Levene 1953). Similarly, selective pressures can cycle through time, and one allele may be alternatively favored and disfavored (Gillespie 1973). Thus, both spatially and temporally varying selection can result in different forms of local adaptation (Ewing 1979).

Spatial heterogeneity generates a pattern of geographical variation in traits that affect fitness (Kawecki and Ebert 2004). Some species can be found along gradually changing environments, and traits that vary with the environment are called clinal. Examples of clinal variation are abundant in many different taxa, such as thale cress (Zuther et al. 2012), monkeyflowers (Kooyers et al. 2015), ivyleaf morning glories (Campitelli and Stinchcombe 2013), Atlantic salmons (Dionne et al. 2007), vervet monkeys (Cardini et al. 2007) and even humans (Hancock et al. 2008).

Drosophila melanogaster has been used as a model to understand latitudinal variation because, besides being a genetic model, it is a sub-Saharan fly species that has recently invaded most of the world (David and Capy 1988). These flies migrated into Eurasia approximately 15,000 years ago (Li and Stephan 2006), but the colonization of the Americas and Australia likely happened in a single event within the last several hundred years (Bock and Parsons 1981; Keller 2007). The establishment of populations in dramatically different environments (e.g., temperate regions), is thought to have resulted in several climatic adaptations (David and Capy 1988). 
Clinal variation has been documented for this species in many characters both at the phenotypic and genetic level. For instance, at the phenotypic level, flies from higher latitudes are darker (David et al. 1985), bigger (Arthur et al. 2008) and show higher incidence of reproductive diapause (Schmidt et al. 2005). At the genetic level, latitudinal clines have been identified for allozymes, chromosome inversions and single nucleotide polymorphisms (Mettler et al. 1977; Knibb 1982; Oakeshott et al. 1982; Schmidt et al. 2000; de Jong and Bochdanovits 2003; Sezgin et al. 2004; Fabian et al. 2012; Kapun et al. 2016).

These clinal traits in D. melanogaster are usually thought to be a result of spatially varying selection (Endler 1977). Although a covariation between an environmental variable and a trait is suggestive of natural selection, non-adaptive processes such as isolation by distance, range expansion and admixture can produce similar patterns of spatial change (Wright 1943; Vasemägi 2006; Excoffier et al. 2009; Duchen et al. 2013; Bergland et al. 2016). Because latitudinal clines are often repeated (e.g., across continents), a classical approach to discern between adaptive and neutral differentiation has been to look at parallel clinal variation (Hoffmann et al. 2002; Hoffmann and Weeks 2007; Turner et al. 2008; Paaby et al. 2010; Reinhardt et al. 2014; Schrider et al. 2016). If a trait varies clinally in two or more continents, a simple, plausible scenario is latitudinally varying selection acting on ancestral variation (Endler 1977; Barton 1983; Barton 1999).

A recent study showed that parallel clinal variation between continents could be a result of secondary contact among previously diverged populations of D. melanogaster (Bergland et al. 2016). It appears that part of the clinality observed in flies from the east coast of North America and Australia can be attributed to migration of European flies to the high latitude end of the cline and migration of African flies to low latitude locations. 
As a consequence, it may be impossible to distinguish adaptive from neutral clines just by looking at patterns of clinal variation.

To reject some of these non-adaptive hypothesis, one would need access to population parameters that are hard to measure or estimate, such as the distribution of fitness effects, landscape of recombination rate, rates of migration, population sizes, changes in population size and historical founding of the populations. Alternatively, one approach to disentangle adaptive from non-adaptive processes is by exploring signatures of parallel variation between latitude and seasons (Cogni et al. 2015).

Drosophila has also been widely used in the study of seasonal adaptation. One of the earliest examples of seasonal variation was observed in chromosomal inversions in D. pseudoobscura (Dobzhansky 1943). In D. melanogaster, it has been shown that flies collected in the spring are more tolerant to stress (Behrman et al. 2015), show higher diapause inducibility (Schmidt and Conde 2006), have increased immune function (Behrman et al. 2018) and have different cuticular hydrocarbon profiles than those collected in the fall (Rajpurohit et al. 2017). These studies were either conducted in a common laboratory condition or as a field based mesocosm experiment. Furthermore, genome-wide analysis have identified polymorphisms that oscillate in seasonal timescales in several localities in the United States and Europe (Bergland et al. 2014; Machado et al. 2018).

Many environmental variables that vary along a latitudinal transect vary in a similar fashion through seasons. Processes that can generate clinal patterns like isolation by distance and secondary contact from diverged populations are independent to variation across seasons. Therefore, traits that vary both with latitude and through seasons are likely under natural selection. For instance, it has been observed in $D$. melanogaster that both the prevalence of reproductive diapause and the frequency of a 
variant in the couch potato gene associated with diapause inducibility vary latitudinally and seasonally (Schmidt et al. 2005; Cogni et al. 2014). The frequency of this diapauseinducing variant drops in the summer and is positively correlated with latitude.

Very few studies have tried to identify parallel clinal and seasonal variation in $D$. melanogaster (Bergland et al. 2014; Cogni et al. 2015; Machado et al. 2018). The association between clinal and seasonal change has been identified in central metabolic genes, which is likely caused by parallel climatic factors driving adaptation in these genes (Cogni et al. 2015). This study focused on a limited number of polymorphisms in metabolic genes. Bergland et al. (2014) found an indicative that clinal variants are more likely to be seasonal. A very recent study observed that seasonal changes mirrors latitudinal changes in D. melanogaster with the intent of validating seasonal outliers (Machado et al. 2018), using few seasonal samples from many different locations.

Here, we aim to answer whether the clinal patterns observed in D. melanogaster are consistent with the action of natural selection. We do so by looking at parallel clinal and seasonal variation across the genome. Because many environmental variables such as temperature, $\mathrm{UV}$ radiation and resource availability vary similarly across latitude and through seasons in a temperate environment, we hypothesize there is a relationship between clinal and seasonal variation. Flies collected in the north should be more similar to flies collected in early spring, whereas southern flies should be more like fall flies. We also tested whether the pattern of clinal mirroring seasonal variation is consistent with selection. Finally, by looking at the relationship between clinal and seasonal variation, we asked how much of the genome is under spatial and seasonal selection. Integrating these two independent sources of evidence can help us disentangle adaptive from non-adaptive processes that contribute to the pervasive and long standing patterns of clinal variation in D. melanogaster. 


\section{Conclusion}

Many species occur along spatially structured environments, and show clinal variation in many traits, so a question that remains open is whether these patterns are the result of natural selection or neutral demographic processes. Temporal variation is also ubiquitous, especially in temperate environments, so seasonal adaptation could be an important feature of organisms that have multiple generations each year (also called multivoltine) (Behrman et al. 2015). Here, we demonstrate that by integrating clinal and seasonal variation, it is possible to discern adaptive and non-adaptive hypothesis for clinal variation. This approach could potentially be applied to other multivoltine species that occur along environmental gradients. Notably, this approach can be applied in invasive species, which are known to often have short-generation times and to reproduce quickly (Sakai et al. 2001). Our data is consistent with the adaptive hypothesis for clinal variation in D. melanogaster, and our results could hold for many of the other species which show clinal variation in natural populations. 


\section{References}

Adrion JR, Hahn MW, Cooper BS. 2015. Revisiting classic clines in Drosophila melanogaster in the age of genomics. Trends Genet. 31:434-444.

Agis M, Schlötterer C. 2001. Microsatellite variation in natural Drosophila melanogaster populations from New South Wales (Australia) and Tasmania. Mol. Ecol. 10:1197-1205.

Andolfatto P. 2005. Adaptive evolution of non-coding DNA in Drosophila. Nature 437:1149-1152.

Arthur AL, Weeks AR, Sgrò CM. 2008. Investigating latitudinal clines for life history and stress resistance traits in Drosophila simulans from eastern Australia. J. Evol. Biol. 21:1470-1479.

Ashburner M, Ball CA, Blake JA, Botstein D, Butler H, Cherry JM, Davis AP, Dolinski K, Dwight SS, Eppig JT, et al. 2000. Gene ontology: tool for the unification of biology. The Gene Ontology Consortium. Nat. Genet. 25:25-29.

Bansal V, Bansal V, Libiger O. 2016. A statistical method for the detection of variants from next-generation resequencing of DNA pools. Bioinformatics 32:3213.

Barton NH. 1983. Multilocus clines. Evolution 37:454-471.

Barton NH. 1999. Clines in polygenic traits. Genet. Res. 74:223-236.

Baxter I, Brazelton JN, Yu D, Huang YS, Lahner B, Yakubova E, Li Y, Bergelson J, Borevitz JO, Nordborg M, et al. 2010. A Coastal Cline in Sodium Accumulation in Arabidopsis thaliana Is Driven by Natural Variation of the Sodium Transporter AtHKT1;1. PLoS Genet. 6:e1001193.

Behrman EL, Howick VM, Kapun M, Staubach F, Bergland AO, Petrov DA, Lazzaro BP, Schmidt PS. 2018. Rapid seasonal evolution in innate immunity of wild Drosophila melanogaster. Proc. Biol. Sci. [Internet] 285. Available from: http: / / dx.doi.org/10.1098/rspb.2017.2599

Behrman EL, Watson SS, O'Brien KR, Heschel MS, Schmidt PS. 2015. Seasonal variation in life history traits in two Drosophila species. J. Evol. Biol. 28:1691-1704.

Bergland AO, Behrman EL, O'Brien KR, Schmidt PS, Petrov DA. 2014. Genomic evidence of rapid and stable adaptive oscillations over seasonal time scales in Drosophila. PLoS Genet. 10:e1004775.

Bergland AO, Tobler R, González J, Schmidt P, Petrov D. 2016. Secondary contact and local adaptation contribute to genome-wide patterns of clinal variation in Drosophila melanogaster. Mol. Ecol. 25:1157-1174. 
Bock IR, Parsons PA. 1981. Species of Australia and New Zealand. Genetics and biology of Drosophila 3:291-308.

Campitelli BE, Stinchcombe JR. 2013. Natural selection maintains a single-locus leaf shape cline in Ivyleaf morning glory, Ipomoea hederacea. Mol. Ecol. 22:552-564.

Cardini A, Jansson A-U, Elton S. 2007. A geometric morphometric approach to the study of ecogeographical and clinal variation in vervet monkeys. J. Biogeogr. 34:1663-1678.

Cingolani P, Platts A, Wang LL, Coon M, Nguyen T, Wang L, Land SJ, Lu X, Ruden DM. 2012. A program for annotating and predicting the effects of single nucleotide polymorphisms, SnpEff: SNPs in the genome of Drosophila melanogaster strain w1118; iso-2; iso-3. Fly 6:80-92.

Cogni R, Kuczynski C, Koury S, Lavington E, Behrman EL, O’Brien KR, Schmidt PS, Eanes WF. 2014. The intensity of selection acting on the couch potato gene-spatial-temporal variation in a diapause cline. Evolution 68:538-548.

Cogni R, Kuczynski K, Lavington E, Koury S, Behrman EL, O’Brien KR, Schmidt PS, Eanes WF. 2015. Variation in Drosophila melanogaster central metabolic genes appears driven by natural selection both within and between populations. Proceedings of the Royal Society of London B: Biological Sciences 282:20142688.

Comeron JM, Ratnappan R, Bailin S. 2012. The many landscapes of recombination in Drosophila melanogaster. PLoS Genet. 8:e1002905.

Coyne JA, Beecham E. 1987. Heritability of two morphological characters within and among natural populations of Drosophila melanogaster. Genetics 117:727-737.

David J, Capy P, Payant V, Tsakas S. 1985. Thoracic trident pigmentation in Drosophila melanogaster: Differentiation of geographical populations. Genet. Sel. Evol. 17:211-224.

David JR, Bocquet C. 1975a. Evolution in a cosmopolitan species: Genetic latitudinal clines inDrosophila melanogaster wild populations. Experientia 31:164166.

David JR, Bocquet C. 1975b. Similarities and differences in latitudinal adaptation of two Drosophila sibling species. Nature 257:588-590.

David JR, Capy P. 1988. Genetic variation of Drosophila melanogaster natural populations. Trends Genet. 4:106-111.

Dionne M, Miller KM, Dodson JJ, Caron F, Bernatchez L. 2007. Clinal variation in MHC diversity with temperature: evidence for the role of host-pathogen interaction on local adaptation in Atlantic salmon. Evolution 61:2154-2164.

Dobzhansky T. 1943. Genetics of Natural Populations IX. Temporal Changes in the Composition of Populations of Drosophila Pseudoobscura. Genetics 28:162-186. 
Duchen P, Zivkovic D, Hutter S, Stephan W, Laurent S. 2013. Demographic inference reveals African and European admixture in the North American Drosophila melanogaster population. Genetics 193:291-301.

Endler JA. 1977. Geographic variation, speciation, and clines. Monogr. Popul. Biol. 10:1-246.

Ewing EP. 1979. Genetic Variation in a Heterogeneous Environment VII. Temporal and Spatial Heterogeneity in Infinite Populations. Am. Nat. 114:197-212.

Excoffier L, Foll M, Petit RJ. 2009. Genetic Consequences of Range Expansions. Annu. Rev. Ecol. Evol. Syst. 40:481-501.

Fabian DK, Kapun M, Nolte V, Kofler R, Schmidt PS, Schlötterer C, Flatt T. 2012. Genome-wide patterns of latitudinal differentiation among populations of Drosophila melanogaster from North America. Mol. Ecol. 21:4748-4769.

Feder AF, Petrov DA, Bergland AO. 2012. LDx: estimation of linkage disequilibrium from high-throughput pooled resequencing data. PLoS One 7:e48588.

Fisher RA. 1992. Statistical Methods for Research Workers. In: Kotz S, Johnson NL, editors. Breakthroughs in Statistics: Methodology and Distribution. New York, NY: Springer New York. p. 66-70.

García-Vázquez E, Sánchez-Refusta F. 1988. Chromosomal polymorphism and extra bristles of Drosophila melanogaster: joint variation under selection in isofemale lines. Genetica 78:91-96.

Gillespie J. 1973. Polymorphism in random environments. Theor. Popul. Biol. 4:193-195.

Gramates LS, Marygold SJ, Santos GD, Urbano J-M, Antonazzo G, Matthews BB, Rey AJ, Tabone CJ, Crosby MA, Emmert DB, et al. 2017. FlyBase at 25: looking to the future. Nucleic Acids Res. 45:D663-D671.

Hancock AM, Witonsky DB, Gordon AS, Eshel G, Pritchard JK, Coop G, Di Rienzo A. 2008. Adaptations to climate in candidate genes for common metabolic disorders. PLoS Genet. 4:e32.

Hoffmann AA, Anderson A, Hallas R. 2002. Opposing clines for high and low temperature resistance in Drosophila melanogaster. Ecol. Lett. 5:614-618.

Hoffmann AA, Scott M, Partridge L, Hallas R. 2003. Overwintering in Drosophila melanogaster: outdoor field cage experiments on clinal and laboratory selected populations help to elucidate traits under selection. J. Evol. Biol. 16:614-623.

Hoffmann AA, Weeks AR. 2007. Climatic selection on genes and traits after a 100 year-old invasion: a critical look at the temperate-tropical clines in Drosophila melanogaster from eastern Australia. Genetica 129:133-147. 
de Jong G, Bochdanovits Z. 2003. Latitudinal clines inDrosophila melanogaster: Body size, allozyme frequencies, inversion frequencies, and the insulin-signalling pathway. J. Genet. 82:207-223.

Kao JY, Zubair A, Salomon MP, Nuzhdin SV, Campo D. 2015. Population genomic analysis uncovers African and European admixture in Drosophila melanogaster populations from the south-eastern United States and Caribbean Islands. Mol. Ecol. 24:1499-1509.

Kapun M, Aduriz MGB, Staubach F, Vieira J, Obbard D, Goubert C, Stabelli OR, Kankare M, Haudry A, Wiberg RAW, et al. 2018. Genomic analysis of European Drosophila populations reveals longitudinal structure and continent-wide selection. bioRxiv [Internet]:313759. Available from: https: / / www.biorxiv.org/content/ early/2018/06/04/313759

Kapun M, Fabian DK, Goudet J, Flatt T. 2016. Genomic Evidence for Adaptive Inversion Clines in Drosophila melanogaster. Mol. Biol. Evol. 33:1317-1336.

Kapun M, van Schalkwyk H, McAllister B, Flatt T, Schlötterer C. 2014. Inference of chromosomal inversion dynamics from Pool-Seq data in natural and laboratory populations of Drosophila melanogaster. Mol. Ecol. 23:1813-1827.

Kawecki TJ, Ebert D. 2004. Conceptual issues in local adaptation. Ecol. Lett. 7:12251241.

Keller A. 2007. Drosophila melanogaster's history as a human commensal. Curr. Biol. 17:R77-R81.

Kennington WJ, Killeen JR, Goldstein DB, Partridge L. 2003. Rapid laboratory evolution of adult wing area in Drosophila melanogaster in response to humidity. Evolution 57:932-936.

Knibb WR. 1982. Chromosome inversion polymorphisms in Drosophila melanogaster II. Geographic clines and climatic associations in Australasia, North America and Asia. Genetica 58:213-221.

Kofler R, Orozco-terWengel P, De Maio N, Pandey RV, Nolte V, Futschik A, Kosiol C, Schlötterer C. 2011. PoPoolation: A Toolbox for Population Genetic Analysis of Next Generation Sequencing Data from Pooled Individuals. PLoS One 6:e15925.

Kofler R, Schlötterer C. 2012. Gowinda: unbiased analysis of gene set enrichment for genome-wide association studies. Bioinformatics 28:2084-2085.

Kolaczkowski B, Kern AD, Holloway AK, Begun DJ. 2011. Genomic differentiation between temperate and tropical Australian populations of Drosophila melanogaster. Genetics 187:245-260.

Kooyers NJ, Greenlee AB, Colicchio JM, Oh M, Blackman BK. 2015. Replicate altitudinal clines reveal that evolutionary flexibility underlies adaptation to drought stress in annual Mimulus guttatus. New Phytol. 206:152-165. 
Lavington E, Cogni R, Kuczynski C, Koury S, Behrman EL, O’Brien KR, Schmidt PS, Eanes WF. 2014. A small system--high-resolution study of metabolic adaptation in the central metabolic pathway to temperate climates in Drosophila melanogaster. Mol. Biol. Evol. 31:2032-2041.

Levene H. 1953. Genetic Equilibrium When More Than One Ecological Niche is Available. Am. Nat. 87:331-333.

Li H, Durbin R. 2010. Fast and accurate long-read alignment with Burrows-Wheeler transform. Bioinformatics 26:589-595.

Li H, Stephan W. 2006. Inferring the demographic history and rate of adaptive substitution in Drosophila. PLoS Genet. 2:e166.

Lynch M, Bost D, Wilson S, Maruki T, Harrison S. 2014. Population-genetic inference from pooled-sequencing data. Genome Biol. Evol. 6:1210-1218.

Machado HE, Bergland AO, O'Brien KR, Behrman EL, Schmidt PS, Petrov DA. 2016. Comparative population genomics of latitudinal variation in Drosophila simulans and Drosophila melanogaster. Mol. Ecol. 25:723-740.

Machado HE, Bergland AO, Taylor R, Tilk S, Behrman E, Dyer K, Fabian DK, Flatt T, González J, Karasov TL, et al. 2018. Broad geographic sampling reveals predictable and pervasive seasonal adaptation in Drosophila. Available from: http: / / dx.doi.org/10.1101/337543

Mackay TFC, Richards S, Stone EA, Barbadilla A, Ayroles JF, Zhu D, Casillas S, Han Y, Magwire MM, Cridland JM, et al. 2012. The Drosophila melanogaster Genetic Reference Panel. Nature 482:173-178.

McKenna A, Hanna M, Banks E, Sivachenko A, Cibulskis K, Kernytsky A, Garimella K, Altshuler D, Gabriel S, Daly M, et al. 2010. The Genome Analysis Toolkit: a MapReduce framework for analyzing next-generation DNA sequencing data. Genome Res. 20:1297-1303.

Mettler LE, Voelker RA, Mukai T. 1977. Inversion Clines in Populations of Drosophila melanogaster. Genetics 87:169-176.

Mitrovski P, Hoffmann AA. 2001. Postponed reproduction as an adaptation to winter conditions in Drosophila melanogaster: evidence for clinal variation under semi-natural conditions. Proc. Biol. Sci. 268:2163-2168.

Oakeshott JG, Gibson JB, Anderson PR, Knibb WR, Anderson DG, Chambers GK. 1982. Alcohol dehydrogenase and glycerol-3-phosphate dehydrogenase clines in Drosophila melanogaster on different continents. Evolution 36:86-96.

Paaby AB, Blacket MJ, Hoffmann AA, Schmidt PS. 2010. Identification of a candidate adaptive polymorphism for Drosophila life history by parallel independent clines on two continents. Mol. Ecol. 19:760-774. 
Pavlidis P, Jensen JD, Stephan W, Stamatakis A. 2012. A critical assessment of storytelling: gene ontology categories and the importance of validating genomic scans. Mol. Biol. Evol. 29:3237-3248.

Rajpurohit S, Hanus R, Vrkoslav V, Behrman EL, Bergland AO, Petrov D, Cvačka J, Schmidt PS. 2017. Adaptive dynamics of cuticular hydrocarbons in Drosophila. J. Evol. Biol. 30:66-80.

R Core Team. 2018. R: A Language and Environment for Statistical Computing. Available from: https: / / www.R-project.org/

Reinhardt JA, Kolaczkowski B, Jones CD, Begun DJ, Kern AD. 2014. Parallel Geographic Variation in Drosophila melanogaster. Genetics 197:361-373.

Sakai AK, Allendorf FW, Holt JS, Lodge DM, Molofsky J, With KA, Baughman S, Cabin RJ, Cohen JE, Ellstrand NC, et al. 2001. The Population Biology of Invasive Species. Annu. Rev. Ecol. Syst. 32:305-332.

Schmidt PS, Conde DR. 2006. Environmental heterogeneity and the maintenance of genetic variation for reproductive diapause in Drosophila melanogaster. Evolution 60:1602-1611.

Schmidt PS, Duvernell DD, Eanes WF. 2000. Adaptive evolution of a candidate gene for aging in Drosophila. Proc. Natl. Acad. Sci. U. S. A. 97:10861-10865.

Schmidt PS, Matzkin L, Ippolito M, Eanes WF, Hey J. 2005. Geographic variation in diapause incidence, life-history traits, and climatic adaptation in Drosophila melanogaster. Evolution 59:1721-1732.

Schrider DR, Hahn MW, Begun DJ. 2016. Parallel evolution of copy-number variation across continents in Drosophila melanogaster. Mol. Biol. Evol. 33:13081316.

Sezgin E, Duvernell DD, Matzkin LM, Duan Y, Zhu C-T, Verrelli BC, Eanes WF. 2004. Single-locus latitudinal clines and their relationship to temperate adaptation in metabolic genes and derived alleles in Drosophila melanogaster. Genetics 168:923-931.

Singh RS, Rhomberg LR. 1987a. A Comprehensive Study of Genic Variation in Natural Populations of Drosophila melanogaster. II. Estimates of Heterozygosity and Patterns of Geographic Differentiation. Genetics 117:255-271.

Singh RS, Rhomberg LR. 1987b. A Comprehensive Study of Genic Variation in Natural Populations of Drosophila melanogaster. I. Estimates of Gene Flow from Rare Alleles. Genetics 115:313-322.

Smith JM, Haigh J. 1974. The hitch-hiking effect of a favourable gene. Genet. Res. 23:23-35.

Turner TL, Levine MT, Eckert ML, Begun DJ. 2008. Genomic analysis of adaptive 
differentiation in Drosophila melanogaster. Genetics 179:455-473.

Vasemägi A. 2006. The adaptive hypothesis of clinal variation revisited: singlelocus clines as a result of spatially restricted gene flow. Genetics 173:2411-2414.

Wright S. 1943. Isolation by distance. Genetics 28:114-138.

Wright S, Dobzhansky T. 1946. Genetics of natural populations; experimental reproduction of some of the changes caused by natural selection in certain populations of Drosophila pseudoobscura. Genetics 31:125-156.

Zuther E, Schulz E, Childs LH, Hincha DK. 2012. Clinal variation in the nonacclimated and cold-acclimated freezing tolerance of Arabidopsis thaliana accessions. Plant Cell Environ. 35:1860-1878. 